\title{
КЛІНІКО-БІОХІМІЧНІ ЗМІНИ КРОВІ ЩУРІВ ІЗ МОДЕЛЬОВАНИМ ГАЛАКТОЗАМІНОВИМ ГЕПАТИТОМ НА ТЛІ МЕРКАЗОЛІЛІНДУКОВАНОГО ГІПОТИРЕОЗУ
}

\begin{abstract}
Резюме. На сьогодні захворювання щитоподібної залози (ЩЗ) за своєю поширеністю займають одне з перших місць серед ендокринних патологій у багатьох країнах. Гормони щз регулюють рівень базального метаболізму усіх клітин, включаючи гепатоцити, що позначається на функціонуванні печінки, а печінка, у свою чергу, метаболізує тиреотропний гормон (ТГ). Порушення фрункції щ3 можуть призводити до змін фрункцій печінки, а при захворюваннях печінки можуть виникати відхилення в метаболізмі ТГ. Печінці належить центральна роль у дейодуванні ТГ з утворенням їх активних або інактивованих форм. Дефіцит гормонів щз в організмі призводить до порушення водно-електролітного, білкового, ліпідного, вуглеводного обмінів, спричиняючи морфофункціональні та біохімічні зміни в різних органах і системах.

Мета дослідження - вивчити динаміку змін біохімічних показників у крові та тканині печінки щурів із гострим гепатитом на тлі мерказоліліндукованого гіпотиреозу.

Матеріали і методи. У даній роботі представлено дослідження динаміки змін біохімічних показників у крові та тканині печінки щурів із гострим гепатитом на тлі мерказоліліндукованого гіпотиреозу. Виходячи з цього, гіпотиреоз моделювали щоденним введенням per os за допомогою спеціального зонда фармакопейного тиреостатика мерказолілу. Контроль здійснювали за рівнем тироксину, трийодтироніну і тиреотропного гормону, а також за масою тварин і їх руховою активністю. Групу порівняння склали тварини, яким мерказоліл не вводили. Вплив гіпотиреозу на перебіг запального процесу в печінці вивчали на моделі галактозамінового гепатиту, який викликали шляхом внутрішньочеревного уведення піддослідним тваринам галактозаміну. Через 1-шу і 7-му доби після моделювання гепатиту щурів декапітували під тіопенталовим наркозом.

Результати досліджень та їх обговорення. В експерименті на щурах вивчено особливості динаміки біохімічних показників у крові й гомогенаті печінки за умови модельованого галактозамінового гепатиту на тлі гіпотиреозу. При цьому встановлено, що токсичне ушкодження печінки в щурів супроводжується активацією системної відповіді місцевої запальної реакції, збільшенням вмісту активних нейтрофілів у периферійній крові, спричиненої інтенсифікацією неспецифрічних фракторів імунного захисту, зменшення показників резерву та біохімічних показників тіол-дисульфідної системи.

Висновки. У щурів із модельованим гіпотиреозом зафіксовано зменшення показників глутатіонового ланцюга тіол-дисульфідної системи, а саме, глутатіонпероксидази (ГП), глутатіонредуктази (ГР) та поканика відновленого глутатіону. Також виявлено підвищеня покаників сНСТ й іНСТ. За умови гострого галактозамінового гепатиту встановлено зменшення показників глутатіонового ланцюга тіол-дисульфідної системи, а саме, глутатіонпероксидази (ГП), глутатіонредуктази (ГР) та відновленого глутатіону і виявлено підвищеня покаників сНСТ і іНСТ. За умови експериментального галактозамінового гепатиту на тлі гіпотиреозу ми спостерігали аналогічні зміни.
\end{abstract}

Ключові слова: гіпотиреоз; галактозаміновий гепатит; тіол-дисульфідні сполуки; глутатіонпероксидаза; глутатіонредуктаза; відновлений глутатіон; нейтрофріли.

ВСТУП Гіпотиреоз - синдром, що розвивається унаслідок різкого зниження функції щитоподібної залози. На сьогодні хвороби щитоподібної залози за своєю поширеністю займають одне з перших місць серед ендокринних патологій у багатьох країнах світу.

Поширення гіпотиреозу серед населення постійно збільшується. Серед жінок частота його становить від 1,4 до $2 \%$, а серед чоловіків - 0,2 \%. За даними епідеміологічних досліджень, в окремих групах населення поширеність субклінічного гіпотиреозу сягає 10-12 \% [8]. Це порівняно рідкісне захворювання, що буває переважно у жінок 30-60 років, хоча останніми роками відмічають деякий ріст числа хворих із різними формами гіпотиреозу.

Висока частота захворювань щ3 залежить від багатьох причин, серед яких найвагомішими вважають припинення централізованої йодної профілактики, техногенне забруднення довкілля, негативні зміни в структурі харчування у значної частини населення за нових соціально-економічних умов $[4,6,9,10]$.

Дефіцит гормонів щЗ в організмі призводить до порушення водно-електролітного, білкового, ліпідного, вуглеводного обмінів, спричиняючи морфофрункціональні та біохімічні зміни в різних органах і системах.

Гормони щ3 регулюють рівень базального метаболізму усіх клітин, включаючи гепатоцити, що позначається на фрункціонуванні печінки, а вона, у свою чергу, метаболізує ТГ [1]. Порушення фрункції ЩЗ можуть призводити до змін функцій печінки, а при її захворюваннях можуть виникати відхилення в метаболізмі ТГ [1]. Печінці належить центральна роль у дейодуванні ТГ з утворенням їх активних або інактивованих фрорм [3]. Відомо, що в кишечнику не лише всмоктується йод, що міститься в їжі, але й відбувається повторне всмоктування йоду, який вивільняється з печінки в результаті дейодування ТГ, що виділяється 3 жовчю у дванадцятипалу кишку. В результаті 80-90 \% йоду, що міститься в організмі, реутилізується та використовується в повторному біосинтезі ТГ. Тому цілком зрозуміло, що розлад діяльності гепатобіліарної системи може позначитися на метаболізмі цих гормонів. А це особливо важливо ще й тому, що збільшення патології щ3 пов'язують із десріцитом йоду - найважливішого компонента молекули головного гормону щ3 - тироксину. Зниження функції щз може впливати безпосередньо на структуру та фрункцію печінки [3].

Отже, поєднана патологія гепатобіліарної системи та щитоподібної залози є актуальною сучасною проблемою.

Метою дослідження було вивчити динаміку змін біохімічних показників у крові та тканині печінки щурів із гострим гепатитом на тлі мерказоліліндукованого гіпотиреозу.

МАTЕPIАЛИ I МЕТОДИ Дослідження проводили на білих безпородних щурах-самцях масою тіла 180-200 г, яких утримували у віварії ДВНЗ “Тернопільський державний медичний університет імені І. Я. Горбачевського”, відповідно до вимог Правил проведення робіт з використанням експериментальних тварин [7]. Тварини перебували на повноцінному раціоні віварію з вільним доступом до води. 
Гіпотиреоз моделювали щоденним введенням per os за допомогою спеціального зонда фрармакопейного тиреостатика мерказолілу (“Здоров'я", Україна) у дозі 25 мг/кг протягом 21-ї доби. Контроль здійснювали за рівнем тироксину, трийодтироніну і тиреотропного гормону, а також за масою тварин і їх руховою активністю. До групи порівняння входили тварини, яким мерказоліл не вводили.

Вплив гіпотиреозу на перебіг запального процесу в печінці вивчали на моделі галактозамінового гепатиту, який викликали шляхом внутрішньочеревного введення піддослідним тваринам галактозаміну в дозі 400 мг/кг у вигляді $20 \%$ розчину [5]. Через 1-шу і 7-му доби після моделювання гепатиту щурів декапітували під тіопенталовим наркозом (50 мг/кг). Групами порівняння слугували тварини 3 експериментальним гіпотиреозом і щури 3 токсичним галактозаміновим гепатитом. Контролем був матеріал від інтактних тварин.

Функціональну активність нейтросрілів оцінювали за допомогою спонтанного НСТ-тесту (сНСТ-тест). Для визначення фрункціонального резерву нейтрофрілів використовували індукований НСТ-тест (іНСТ-тест). Розраховували показник резерву (ПР) за фрормулою іНСТ/сНСТ, а також коефріцієнт метаболічної активації нейтрофрілів (Какт) за формулою: іНСТ - сHCT/iНCT [2].

Надосадову частину гомогенату печінки використовували для визначення вмісту тіол-дисульфрідних сполук і відновленого глутатіону (ВГ).

Вміст ВГ у гомогенаті печінки і гемолізаті еритроцитів визначали методом Ellman G [2]. Концентрацію глутатіону виражали в гомогенаті печінки і в гемолізаті у мг/л.

Обробку результатів виконано у відділі системних статистичних досліджень. Для всіх показників розраховували значення середньої арифметичної вибірки (М), її дисперсії і помилки середньої (m). Достовірність різниці значень між незалежними кількісними величинами визначали при нормальному розподілі за критерієм Стьюдента, в інших випадках - за допомогою U-критерію МаннаУїтні. Аналіз кореляційних зв'язків отриманих результатів проводили з використанням статистики Спірмена [2].
РЕЗУЛЬТАТИ ДОСЛІДЖЕНЬ ТА ЇХ ОБГОВОРЕННЯ За результатами проведеного дослідження виявлено зниження активності ферментів глутатіонового ланцюга тіол-дисульфрідної системи (глутатіонпероксидази (ГП), глутатіонредуктази (ГР) та вмісту відновленого глутатіону (табл. 1).

Виходячи з результатів проведеного дослідження, показник відновленого глутатіону (ВГ) у щурів з експериментальним гіпотиреозом зменшився у 1,5 раза відносно інтактних тварин (табл. 1). Також через одну добу після моделювання гепатиту вміст ВГ знизився у 1,2 раза, а через 7 діб даний показник зменшився в 1,4 раза відносно інтактних тварин. Відповідно і рівень ВГ у тварин, яким гострий гепатит моделювали на тлі гіпотиреозу, через одну добу після експерименту знизився в 1,6 раза, а через 7 діб даний показник зменшився у 1,6 раза відносно інтактних щурів.

Також досліджували показник глутатіопероксидази (ГП) у тварин, у результаті чого було виявлено, що рівень ГП у щурів із модельованим гіпотиреозом зменшився у 1,0 рази відносно інтактних тварин (табл. 1). Також через одну добу після моделювання гепатиту вміст ГП знизився у 1,3 раза, а через 7 діб даний показник зменшився у 1,5 раза відносно інтактних щурів. Відповідно і рівень ГП у тварин, яким гострий гепатит моделювали на тлі гіпотиреозу, через одну добу після експерименту знизився в 2,4 раза, а через 7 діб даний показник зменшився в 2,1 раза відповідно відносно інтактних тварин.

Показник глутатіонредуктази (ГР) у щурів з експериментальним гіпотиреозом зменшився у 1,2 раза відносно інтактних тварин (табл. 1). Через одну добу після моделювання гепатиту вміст ГР знизився у 1,2 раза, а через 7 діб даний показник зменшився в 1,3 раза відносно інтактних тварин. Відповідно і рівень ГР у тварин, яким гострий гепатит моделювали на тлі гіпотиреозу, через одну добу після експерименту знизився в 1,5 раза, а через 7 діб даний показник був нижчим у 1,5 раза відносно інтактних тварин.

Функціональну активність нейтросрілів оцінювали за допомогою спонтанного НСТ-тесту (сНСТ-тест). Для ви-

Таблиця 1. Біохімічні показники тіол-дисульфідної системи, $\mathrm{M \pm m}$

\begin{tabular}{|c|c|c|c|c|c|c|}
\hline \multirow{2}{*}{$\begin{array}{c}\text { Показник/ } \\
\text { група тварин }\end{array}$} & \multirow{2}{*}{$\begin{array}{c}\text { Інтактні тварини } \\
(\mathrm{n}=6)\end{array}$} & \multirow{2}{*}{$\begin{array}{l}\text { Гіпотиреоз } \\
\qquad(\mathrm{n}=6)\end{array}$} & \multicolumn{2}{|c|}{ Галактозаміновий гепатит } & \multicolumn{2}{|c|}{ Гепатит+гіпотиреоз } \\
\hline & & & $\begin{array}{c}\text { 1-ша доба } \\
(n=6)\end{array}$ & $\begin{array}{c}\text { 7-ма доба } \\
(n=6)\end{array}$ & $\begin{array}{c}\text { 1-ша доба } \\
(n=6)\end{array}$ & $\begin{array}{c}\text { 7-ма доба } \\
(n=6)\end{array}$ \\
\hline ВГ (мг/л) & $3,92 \pm 0,19$ & $\begin{array}{c}2,66 \pm 0,11 \\
p<0,05\end{array}$ & $\begin{array}{c}3,23 \pm 0,02 \\
p<0,05 \\
p_{1}<0,05\end{array}$ & $\begin{array}{c}2,47 \pm 0,09 \\
p<0,05 \\
p_{1}<0,05 \\
p_{2}<0,05\end{array}$ & $\begin{array}{c}2,85 \pm 0,02 \\
p<0,05 \\
p_{1}<0,05 \\
p_{3}<0,05\end{array}$ & $\begin{array}{c}2,45 \pm 0,02 \\
p<0,05 \\
p_{1}>0,05 \\
p_{2}<0,05 \\
p_{3}<0,05\end{array}$ \\
\hline $\begin{array}{l}\text { ГП (нмоль/хв на } 1 \text { мг } \\
\text { білка) }\end{array}$ & $1,02 \pm 0,008$ & $\begin{array}{c}0,98 \pm 0,03 \\
p<0,05\end{array}$ & $\begin{array}{c}0,81 \pm 0,09 \\
p<0,05 \\
p_{1}<0,05\end{array}$ & $\begin{array}{c}0,42 \pm 0,02 \\
p<0,05 \\
p_{1}<0,05 \\
p_{2}<0,05\end{array}$ & $\begin{array}{c}0,69 \pm 0,02 \\
p<0,05 \\
p_{1}<0,05 \\
p_{3}<0,05\end{array}$ & $\begin{array}{c}0,48 \pm 0,04 \\
p<0,05 \\
p_{1}>0,05 \\
p_{2}<0,05 \\
p_{3}<0,05\end{array}$ \\
\hline $\begin{array}{l}\text { ГР (нмоль/хв на } 1 \text { мг } \\
\text { білка) }\end{array}$ & $12,98 \pm 0,37$ & $\begin{array}{c}11,04 \pm 0,18 \\
p<0,05\end{array}$ & $\begin{array}{c}10,77 \pm 0,08 \\
p<0,05 \\
p_{1}<0,05\end{array}$ & $\begin{array}{c}8,86 \pm 0,21 \\
p<0,05 \\
p_{1}<0,05 \\
p_{2}<0,05\end{array}$ & $\begin{array}{c}10,27 \pm 0,18 \\
p<0,05 \\
p_{1}<0,05 \\
p_{3}<0,05\end{array}$ & $\begin{array}{c}8,77 \pm 0,22 \\
p<0,05 \\
p_{1}>0,05 \\
p_{2}<0,05 \\
p_{3}<0,05\end{array}$ \\
\hline
\end{tabular}

Примітки: 1) р - достовірність різниці тварин дослідних груп відносно інтактних тварин;

2) $p_{1}$ - достовірність різниці тварин дослідних груп відносно гіпотиреоїдних тварин

3) $\mathrm{p}_{2}$ - достовірність різниці показників у відповідні доби дослідження в межах однієї експериментальної моделі;

4) $p_{3}$ - достовірність різниці еутиреоїдних і гіпотиреоїдних тварин із гострим гепатитом у відповідні доби дослідження. 
значення фрункціонального резерву нейтрофрілів використовували індукований НСТ-тест (іНСТ-тест), а також розраховували показник резерву (ПР).

Зокрема, поканик спонтанного НСТ-тесту (сНСТтест) у щурів з експериментальним гіпотиреозом збільшився у 1,2 раза відносно інтактних тварин (табл. 2). Також через одну добу після моделювання гепатиту поканик сНСТ підвищився у 1,8 раза, а через 7 діб даний показник збільшився в 1,2 раза відносно інтактних тварин. Відповідно і рівень сНСТ у тварин, яким гострий гепатит моделювали на тлі гіпотиреозу, через одну добу після експерименту підвищився в 1,4 раза, а через 7 діб даний показник знизився в 1,2 раза відносно інтактних тварин.

Показник індукованого НСТ-тесту (іНСТ-тест) у щурів з експериментальним гіпотиреозом збільшився у 1,0 рази відносно інтактних тварин (табл. 2). Також через одну добу після моделювання гепатиту вміст іНСТ підвищився у 1,5 раза, а через 7 діб даний показник збільшився в 1,1 раза відносно інтактних тварин. Відповідно і рівень іНСТ у тварин, яким гострий гепатит моделювали на тлі гіпотиреозу, через одну добу після експерименту збільшився в 1,1 раза, а через 7 діб даний показник знизився в 1,5 раза відносно інтактних тварин.

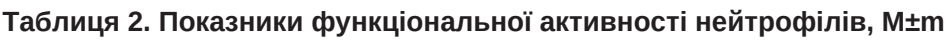

\begin{tabular}{|c|c|c|c|c|c|c|}
\hline \multirow{2}{*}{$\begin{array}{c}\text { Показник/ } \\
\text { група тварин }\end{array}$} & \multirow{2}{*}{$\begin{array}{l}\text { Інтактні тварини } \\
(\mathrm{n}=10)\end{array}$} & \multirow{2}{*}{$\begin{array}{c}\text { Гіпотиреоз } \\
(\mathrm{n}=10)\end{array}$} & \multicolumn{2}{|c|}{ Галактозаміновий гепатит } & \multicolumn{2}{|c|}{ Гепатит+гіпотиреоз } \\
\hline & & & $\begin{array}{c}\text { 1-ша доба } \\
(n=10)\end{array}$ & $\begin{array}{c}\text { 7-ма доба } \\
(n=10)\end{array}$ & $\begin{array}{c}\text { 1-ша доба } \\
(n=10)\end{array}$ & $\begin{array}{c}\text { 7-ма доба } \\
(n=10)\end{array}$ \\
\hline cHCT (\%) & $15,13 \pm 1,37$ & $\begin{array}{c}17,75 \pm 0,77 \\
p<0,05\end{array}$ & $\begin{array}{c}26,59 \pm 1,24 \\
p<0,05 \\
p_{1}<0,05\end{array}$ & $\begin{array}{c}21,11 \pm 0,69 \\
p<0,05 \\
p_{1}<0,05 \\
p_{2}<0,05\end{array}$ & $\begin{array}{c}18,43 \pm 0,53 \\
p<0,05 \\
p_{1}<0,05 \\
p_{3}<0,05\end{array}$ & $\begin{array}{c}13,01 \pm 0,35 \\
p<0,05 \\
p_{1}>0,05 \\
p_{2}<0,05 \\
p_{3}<0,05\end{array}$ \\
\hline iHCT (\%) & $25,76 \pm 0,93$ & $\begin{array}{c}26,84 \pm 1,05 \\
p>0,05\end{array}$ & $\begin{array}{c}38,17 \pm 0,54 \\
p<0,05 \\
p_{1}<0,05\end{array}$ & $\begin{array}{c}29,42 \pm 0,86 \\
p<0,05 \\
p_{1}<0,05 \\
p_{2}<0,05\end{array}$ & $\begin{array}{c}27,85 \pm 0,64 \\
p>0,05 \\
p_{1}>0,05 \\
p_{3}<0,05\end{array}$ & $\begin{array}{c}17,24 \pm 0,64 \\
p^{2}<0,05 \\
p_{1}>0,05 \\
p_{2}>0,05 \\
p_{3}<0,05\end{array}$ \\
\hline ПР (\%) & 1,70 & 1,56 & 1,44 & 1,39 & 1,51 & 1,32 \\
\hline Какт. (\%) & 0,41 & 0,34 & 0,30 & 0,28 & 0,34 & 0,24 \\
\hline
\end{tabular}

Примітки: 1) р - достовірність різниці тварин дослідних груп відносно інтактних тварин;

2) $p_{1}$ - достовірність різниці тварин дослідних груп відносно гіпотиреоїдних тварин

3) $p_{2}$ - достовірність різниці показників у відповідні доби дослідження в межах однієї експериментальної моделі;

4) $p_{3}$ - достовірність різниці еутиреоїдних і гіпотиреоїдних тварин із гострим гепатитом у відповідні доби дослідження.

ВИСНОВКИ 1. У щурів із модельованим гіпотиреозом засріксовано зменшення показників глутатіонового ланцюга тіол-дисульфідної системи, а саме, глутатіонпероксидази (ГП), глутатіонредуктази (ГР) та показника відновленого глутатіону. Також виявлено підвищеня показників сНСТ й іНСТ.
2. За умови гострого галактозамінового гепатиту встановлено зменшення показників глутатіонового ланцюга тіол-дисульфрідної системи, а саме, глутатіонпероксидази (ГП), глутатіонредуктази (ГР) та відновленого глутатіону і виявлено підвищеня покаників сНСТ і іНСТ.

3. За умови експериментального галактозамінового гепатиту на тлі гіпотиреозу ми спостерігали аналогічні зміни.

\section{СПИСОК ЛІТЕРАТУРИ}

1. Аметов А. С. Гіпотиреоз / А. С. Аметов, А. М. ГрабовськаЦветкова // Клініч. фрармакологія і терапія. - 2007. - Т. 6, № 1. - C. 24-28.

2. Лабораторні методи дослідження у біології, тваринництві і ветеринарній медицині : довідник / В.В.Влізло, Р. С. Федорук, І. Б. Ратич [та ін.]. - Львів : СПОЛОМ, 2012. - 764 с.

3. Герок В. В. Захворювання печінки і жовчовивідної системи / В. В. Герок., Х. Е. Блюм. - МЕДпресс-інформ, 2009. - 199 с.

4. Кравченко В. І. Йододесріцит триває - здоров'я населення України погіршується / В. І. Кравченко // Міжнар. ендокринол. журнал. - 2008. - № 6 (18). - С. 9-18.

5. Криницька І. Я. Функціональний стан системи антиоксидантного захисту крові у щурів з модельованим гепатопульмональним синдромом / І. Я. Криницька // Медична хімія. - 2013. - Т. 15, № 1(54). - С. 34-39.
6. Макар Р. Д. Післяопераційний гіпотиреоз: тяжке ускладнення чи прогнозований наслідок лікування? / Р. Д. Макар // Міжнар. ендокринол. журнал. - 2010. - № 1 (25). - С. 90-95.

7. Макарова Н. Г. Структура печени при экспериментальном гипотиреозе / Н. Г. Макарова, Л. С. Васильева, Д. В. Гармаева // Сибирский медицинский журнал. - 2010. - № 3. - С. 70-73.

8. Паньків В. І. Синдром гіпотиреозу / В. І. Паньків // Международный эндокринологический журнал. - 2012. - № 5 (45). - C. $136-148$.

9. Паньків В. І. Практична тиреоїдологія. - Донецьк : Видавець Заславський О. Ю. - 2011. - 224 с.

10. Серцево-судинний ризик на тлі диссрункції щитоподібної залози / О.І. Мітченко, В.Ю. Романов, А.О. Логвиненко [та ін.] // Укр. кардіол. журнал. - 2011. - № 5. - С. 23-29.

Отримано 08.08.18 


\section{CLINICAL-BIOCHEMICAL CHANGES OF RAT'S BLOOD WITH MODELED GALACTOSAMINE HEPATITIS ON THE BACKGROUND} OF MERCAZOLILUM-INDUCED HYPOTHERAPY

Summary. Today, thyroid disease in its prevalence occupies one of the first places among endocrine pathologies in many countries. Thyroid hormones regulate the level of basal metabolism of all cells, including hepatocytes, which affects the functioning of the liver, and the liver, in turn, metabolizes thyroid stimulating hormone (TSH). Disorders of thyroid function may lead to changes in liver function, and in liver disease, there may be a deviation in the metabolism of TSH. The liver has a central role in the dehydration of TSH with the formation of their active or inactivated forms. The deficiency of thyroid hormones in the body leads to a violation of the waterelectrolyte, protein, lipid, carbohydrate metabolism, causing morpho-functional and biochemical changes in various organs and systems. The aim of the study - to learn the dynamics of changes in biochemical parameters in the blood and liver tissue of rats with acute hepatitis against mercazolilum-induced hypothyroidism.

Materials and Methods. In this paper, a study is made of the dynamics of changes in biochemical parameters in blood and liver tissue of rats with acute hepatitis against the background of mercazolilum-induced hypothyroidism. Proceeding from this, hypothyroidism was simulated by daily administration of per os by means of a special probe of pharmacopeial thyreostatics of mercazolilum. Control was performed on the level of thyroxine, triiodothyronine and thyroid stimulating hormone, as well as the weight of animals and their motor activity. The comparison group included animals that Mercazolil was not administered. Influence of hypothyroidism on the course of inflammatory process in the liver was studied on the model of galactosamine hepatitis, which was induced by intraperitoneal administration to the experimental animals of galactosamine. In the $1 \mathrm{st}$ and 7 th day after the modeling of hepatitis, the rats were decapitated under thiopental anesthesia. Results and Discussion. In the experiment on rats, the peculiarities of the dynamics of biochemical parameters in the blood and liver homogenate were studied in the case of simulated galactosamine hepatitis against the background of hypothyroidism. It was found that toxic liver damage in rats is accompanied by the activation of the systemic response of the local inflammatory reaction, an increase in the content of active neutrophils in the peripheral blood caused by the intensification of nonspecific factors of immune defense, reduction of reserve parameters and biochemical parameters of the thiol-disulphide system.

Conclusions. In rats with simulated hypothyroidism, there was a decrease in the indicators of the glutathione chain of the thiol-disulfide system, namely glutathione peroxidase (GP), glutathione reductase (GR) and indicators of reductive glutathione. Also, there was found an increased score of CNST and INF. In acute galactosamine hepatitis, a decrease in the indicators of the glutathione chain of the thiol-disulfide system, namely, glutathione peroxidase (GP), glutathione reductase (GR) and reductive glutathione, has been found, and an increased score for CHCNT and hNST has been found. In experimental galactosamine hepatitis on the background of hypothyroidism, we observed similar changes.

Key words: hypothyroidism; galactosamine hepatitis; thiol-disulphide compounds; glutathione peroxidase; glutathione reductase; reduced glutathione; neutrophils.

๑оО. И. Заричная, И. Н. Клищ

ГВУз “Тернопольский государственный медицинский университет имени И. Я. Горбачевского”

\section{КЛИНИКО-БИОХИМИЧЕСКИЕ ИЗМЕНЕНИЯ КРОВИ КРЫС С МОДЕЛИРУЕМЫМ ГАЛАКТОЗАМИНОВЫМ ГЕПАТИТОМ НА ФОНЕ МЕРКАЗОЛИЛИНДУЦИРОВАННОГО ГИПОТИРЕОЗА}

Резюме. На сегодняшний день заболевания щитовидной железы по своей распространенности занимают одно из первых мест среди эндокринных патологий во многих странах. Гормоны щитовидной железы регулируют уровень базального метаболизма всех клеток, включая гепатоциты, что сказывается на функционировании печени, а печень, в свою очередь, метаболизируется тиреотропный гормон (ТГ). Нарушение функции щитовидной железы могут приводить к изменениям фрункции печени, а при заболеваниях печени могут возникать отклонения в метаболизме ТГ. Печени принадлежит центральная роль в дейодировании ТГ с образованием их активных или инактивированных форм. Дефицит гормонов щитовидной железы в организме приводит к нарушению водно-электролитного, белкового, липидного, углеводного обменов, вызывая морфофуннциональные и биохимические изменения в различных органах и системах.

Цель исследования - изучить динамику изменений биохимических показателей в крови и ткани печени крыс с острым гепатитом на фоне мерказолилиндуцированного гипотиреоза.

Материалы и методы. В данной работе представлено исследование динамики изменений биохимических показателей в крови и ткани печени крыс с острым гепатитом на фоне мерказолилиндуцированного гипотиреоза. Исходя из этого, гипотиреоз моделировали ежедневным введением per os c помощью специального зонда фрармакопейного тиреостатика мерказолила. Контроль осуществляли по уровню тироксина, трийодтиронина и тиреотропного гормона, а также по массе животных и их двигательной активностью. В группу сравнения входили животные, которым мерказолил не вводили. Влияние гипотиреоза на течение воспалительного процесса в печени изучали на модели галактозаминового гепатита, который вызвали путем внутрибрюшного введения подопытным животным галактозамина. Через первый и седьмой день после моделирования гепатита крыс декапитировали под тиопенталовым наркозом.

Результаты исследований и их обсуждение. В эксперименте на крысах изучены особенности динамики биохимических показателей в крови и гомогенате печени при моделируемом галактозаминовым гепатитом на фоне гипотиреоза. При этом установлено, что токсическое повреждение печени у крыс сопровождается активацией системного ответа местной воспалительной реакции, увеличением содержания активных нейтрофилов в периферической крови, вызванной интенсификацией неспецифических фракторов иммунной защиты, уменьшение показателей резерва и биохимических показателей тиол-дисульфидной системы.

Выводы. У крыс с моделируемым гипотиреозом зафиксировано уменьшение показателей глутатионовой цепи тиол-дисульфидной системы, а именно, глутатионпероксидазы (ГП), глутатионредуктазы (ГР) и показателей восстановительного глутатиона. Также обнаружено повышенное показателей сНСТ и іНСТ. При остром галактозаминовом гепатите установлено уменьшение показателей глутатионовой цепи тиол-дисульфидной системы, а именно, глутатионпероксидазы (ГП), глутатионредуктазы (ГР) и восстановительного глутатиона и обнаружено повышенное показателей сНСТ и іНСТ. При экспериментальном галактозаминовом гепатите на фоне гипотиреоза мы наблюдали аналогичные изменения.

Ключевые слова: гипотиреоз; галактозаминовый гепатит; тиол-дисульфидные соединения; глутатионпероксидаза; глутатионредуктаза; восстановленный глутатион; нейтрофилы. 